\title{
Effects of varying forage particle size and fermentable carbohydrates on feed sorting, ruminal fermentation, and milk and component yields of dairy cows ${ }^{1}$
}

\author{
D. D. Maulfair and A. J. Heinrichs ${ }^{2}$ \\ Department of Animal Science, The Pennsylvania State University, University Park 16802
}

\begin{abstract}
Ration sorting is thought to affect ruminal fermentation in such a manner that milk yield milk and components are often decreased. However, the influence of ruminally degradable starch on ration sorting has not been studied. Therefore, the objective of this experiment was to evaluate the interactions between forage particle size (FPS) and ruminally fermentable carbohydrates (RFC) for dry matter intake (DMI), ration sorting, ruminal fermentation, chewing activity, and milk yield and components. In this study, 12 (8 ruminally cannulated) multiparous, lactating Holstein cows were fed a total mixed ration that varied in FPS and RFC. Two lengths of corn silage were used to alter FPS and 2 grind sizes of corn grain were used to alter RFC. It was determined that increasing RFC increased ruminating time and did not affect eating time, whereas increasing FPS increased eating time and did not affect ruminating time. Ruminal fermentation did not differ by altering either FPS or RFC. However, increasing FPS tended to increase mean and maximum ruminal $\mathrm{pH}$ and increasing $\mathrm{RFC}$ tended to decrease minimum ruminal $\mathrm{pH}$. Particle size distribution became more diverse and neutral detergent fiber content of refusals increased over time, whereas starch content decreased, indicating that cows were sorting against physically effective neutral detergent fiber and for RFC. Selection indices determined that virtually no interactions occurred between FPS and RFC and that despite significant sorting throughout the day, by $24 \mathrm{~h}$ after feeding cows had consumed a ration very similar to what was offered. This theory was reinforced by particle fraction intakes that very closely resembled the proportions of particle fractions in the offered total mixed ration. An interaction between FPS and RFC was observed for DMI, as DMI decreased with increasing FPS when the diet included low RFC and did not
\end{abstract}

\footnotetext{
Received August 9, 2012.

Accepted January 5, 2013.

${ }^{1}$ This research was a component of NC-1042, Management Systems to Improve the Economic and Environmental Sustainability of Dairy Enterprise.

${ }^{2}$ Corresponding author: ajh@psu.edu
}

change when the diet included high RFC. Dry matter intake increased with RFC for long diets and did not change with RFC on short diets. Increasing RFC was found to increase milk yield, milk protein content and yield, and lactose content and yield but decrease milk fat content. Increasing FPS did not have as great an effect on milk production as RFC. This study found no significant interaction between FPS and RFC for ration sorting, although an interaction between FPS and RFC for DMI was observed. Neither FPS nor RFC affected ruminal fermentation, whereas RFC had a greater influence on milk yield and components than FPS.

Key words: forage particle size, ruminally fermentable starch, sorting

\section{INTRODUCTION}

Ration sorting is thought to increase cows' susceptibility to SARA. Cows will generally sort for finer particles and against longer particles in their rations, which effectively decreases their fiber intake while increasing their starch intake, as fiber and starch are positively and negatively associated, respectively, with longer particles in dairy cow rations (Leonardi and Armentano, 2003; Leonardi et al., 2005). However, Maulfair et al. (2010) showed drastic increases in refusal particle size distribution and NDF content and decreases in starch content throughout the day, the classical determinants of ration sorting, yet found no negative effects on ruminal fermentation and milk production when cows were fed a ration that contained about 34 and $27 \%$ of ration DM as NDF and starch, respectively.

Ruminally fermentable carbohydrates (RFC) may influence the effective fiber requirement of dairy cows. Yang et al. (2001) suggested that ruminal $\mathrm{pH}$ and SARA cannot be predicted using only physical characteristics of rations, because RFC has a greater influence on ruminal $\mathrm{pH}$ than forage particle size (FPS). Krause et al. (2002b) determined that the physical effectiveness of forages is affected by other dietary components such as corn grain moisture and fermentability. Finally, Krause and Combs (2003) found that significant interactions between FPS and RFC existed for ruminal fermentation and milk production, which indicates that 
effects of FPS and RFC are not always additive, thereby complicating the formulation of dairy rations. None of these studies measured or determined ration sorting when studying the interaction between FPS and RFC; FPS has been shown to have major influence on ration sorting (Kononoff and Heinrichs, 2003; Kononoff et al., 2003b; Leonardi and Armentano, 2003), but effects of $\mathrm{RFC}$ on ration sorting have not been evaluated. Therefore, the objective of this experiment was to study the interactions between FPS and RFC for ration sorting, ruminal fermentation, chewing activity, and milk yield and components.

\section{MATERIALS AND METHODS}

\section{Diets, Cows, and Experimental Design}

Cows used in this research were cared for and maintained according to a protocol approved by The Pennsylvania State University Institutional Animal Care and Use Committee (University Park). Twelve lactating (8 ruminally cannulated), multiparous, Holstein cows, averaging $115 \pm 49$ DIM, weighing $662 \pm$ $64 \mathrm{~kg}$, and with parity of $3.08 \pm 0.79$ (mean $\pm \mathrm{SD}$ ) were studied. The experimental design consisted of 3 replicated, balanced $4 \times 4$ Latin squares with treatments arranged in a $2 \times 2$ factorial design; 2 squares were composed of ruminally cannulated cows. Cows were assigned to squares by parity and randomly assigned to 1 of 4 treatments. Treatments were designed to study the effects of 2 lengths of FPS and 2 levels of RFC. Treatment diets varied in FPS by feeding either long (LCS) or short corn silage (SCS) and RFC were varied by feeding either dry cracked corn (CC) or dry fine ground corn (FC). The 4 treatment diets then consisted of LCS + CC (LC), LCS + FC ( LF), SCS $+\mathrm{CC}(\mathbf{S C})$, and SCS + FC (SF). Except for altering corn silage and grain particle size, the 4 treatment diets contained identical ingredients and proportions. Diet ingredients and their percentage of ration DM were corn silage (42.6), dry ground corn (22.2), alfalfa haylage (15.4), canola meal (9.4), roasted split soybeans (7.1), mineral/vitamin premix (2.5), salt (0.4), and Optigen (0.4; Alltech, Nicholasville, KY). The mineral/vitamin premix contained (\%, as-is basis) trace mineral mix, 0.88; $\mathrm{MgO}(54 \% \mathrm{Mg}), 8.3 ; \mathrm{NaCl}, 6.4$; vitamin $\mathrm{ADE}$ premix, 1.73; limestone, 35.8; selenium premix, 1.09; and dry corn distillers grains with solubles, 45.8; as well as $14.1 \% \mathrm{Ca} ; 0.35 \% \mathrm{P} ; 4.58 \% \mathrm{Mg} ; 0.41 \% \mathrm{~K} ; 0.31 \% \mathrm{~S}$; $1,071 \mathrm{mg}$ of $\mathrm{Mn} / \mathrm{kg} ; 358 \mathrm{mg}$ of $\mathrm{Cu} / \mathrm{kg} ; 1,085 \mathrm{mg}$ of $\mathrm{Zn} /$ $\mathrm{kg} ; 181 \mathrm{mg}$ of $\mathrm{Fe} / \mathrm{kg} ; 6.67 \mathrm{mg}$ of Se/kg; $5.4 \mathrm{mg}$ of Co/ $\mathrm{kg} ; 13.4 \mathrm{mg}$ of I/kg; 262,101 IU of vitamin A/kg; 65,421 IU of vitamin D $/ \mathrm{kg}$; and $1,971 \mathrm{IU}$ of vitamin $\mathrm{E} / \mathrm{kg}$. The study consisted of 4 21-d periods consisting of $14 \mathrm{~d}$ of adaptation followed by a 7 -d collection period.

The corn silage hybrid was Pioneer 34M78 (Pioneer Hi-Bred International Inc., Johnston, IA) that was planted on April 19, 2010, and harvested near soft dent stage on August 30, 2010. Corn silage was harvested with a John Deere 6750 forage harvester (John Deere, Moline, IL) equipped with a kernel processor set at approximately $6.35 \mathrm{~mm}$. The harvester cutterhead used 16 knives (maximum capacity is 48 knives) with the length-of-cut transmission at its highest setting to produce a theoretical length of cut of $47.1 \mathrm{~mm}$. After harvesting, corn silage was ensiled in an Ag-Bag (Ag-Bag, St. Nazianz, WI) and allowed to ferment for $62 \mathrm{~d}$ before beginning the study. Corn silage that was removed from the Ag-Bag and mixed into TMR without further processing was considered LCS. A cutand-throw type, single-row, forage harvester that was modified to operate on a trailer and be fed manually with a 25-horsepower $\mathrm{V}$-Twin small gas engine was used to reduce the particle size of corn silage to produce SCS. Corn silage was rechopped twice through the custom forage chopper on a daily basis to minimize the chemical variance between LCS and SCS. Dry corn was ground through a Roskamp roller mill (California Pellet Mill Co., Crawfordsville, IN) to produce the CC used in this study. This corn was then ground further with a Case International 1250 grinder-mixer (Case $\mathrm{IH}$, Racine, WI) using a 3.18-mm screen to produce FC. Diets were mixed separately using an I. H. Rissler model 1050 TMR mixer (E. Rissler Mfg. LLC, New Enterprise, PA).

Animals were housed in individual stalls in a mechanically ventilated barn, milked twice per day at 0500 and $1700 \mathrm{~h}$, and fed once per day at approximately $0800 \mathrm{~h}$ for ad libitum consumption. Feed refusals were weighed daily and the amount of TMR fed was adjusted daily to maintain a $10 \%$ refusal rate. Feeding once per day at a 10\% refusal rate was designed to allow cattle to have increased opportunity to sort rations. Feed was pushed up 3 times/d at 1230, 1730, and $2400 \mathrm{~h}$. Rations were balanced to meet or exceed NRC (2001) requirements for cows producing $52.2 \mathrm{~kg}$ of milk/d containing $3.75 \%$ fat and $3.07 \%$ true protein, assuming a DMI of 29.5 $\mathrm{kg} / \mathrm{d}$, and water was available for ad libitum consumption.

\section{Chewing Activity}

Eating and rumination behavior were recorded on $\mathrm{d}$ 15 to 21 of each period, using Institute of Grassland and Environmental Research Behavior Recorders and Graze Jaw Movement Analysis Software (Ultra Sound Advice, 
London, UK) as described by Rutter et al. (1997) and Rutter (2000). Chewing was measured for all 12 cows for two 24-h periods including while cows were being milked. These recorders analyze jaw movements of cattle, and the software determines eating or ruminating chews based on the amplitude and frequency of jaw movements. This procedure was validated for use with cows housed in tiestalls by Kononoff et al. (2002).

\section{Rumen Parameters}

Ruminal contents were collected from dorsal, ventral, cranial, caudal, and medial areas of the rumens of all 8 ruminally cannulated cows on $\mathrm{d} 20$ of each period at $0.0,1.5,3.5,5.5,8.5,11.5,14.5,18.0,21.5$, and $24.5 \mathrm{~h}$ after feeding (Kononoff et al., 2003b). At each ruminal sampling, collected digesta was mixed thoroughly and strained through 2 layers of cheesecloth. Rumen fluid $\mathrm{pH}$ was immediately determined using a hand-held pH meter (HI 98121; Hanna Instruments Inc., Woonsocket, RI). Strained ruminal fluid $(15 \mathrm{~mL})$ was placed into bottles containing $3 \mathrm{~mL}$ of $25 \%$ metaphosphoric acid and $3 \mathrm{~mL}$ of $0.6 \%$ 2-ethylbutyric acid (internal standard) and stored at approximately $-20^{\circ} \mathrm{C}$. After thawing, samples were centrifuged 3 times at $4,000 \times$ $g$ for 30 min at $4^{\circ} \mathrm{C}$ to obtain a clear supernatant and were analyzed for VFA concentration using gas chromatography (Yang and Varga, 1989). Rumen ammonia was analyzed using a phenol-hypochlorite assay (Broderick and Kang, 1980). The concentration of lactate in the rumen fluid supernatants was determined using commercially available lactate assay kits (Biomedical Research Service Center, Buffalo, NY).

Finally, rumens of the cannulated cows were completely emptied on d 21 of each period at $5 \mathrm{~h}$ after feeding. The weight and volume of ruminal digesta was then recorded, and digesta was sampled for DM analysis. Digesta was then immediately returned to the rumen of each cow.

\section{Feed, Refusal, and Particle Size Analysis}

Feed bunk contents for each animal were weighed and sampled on d 18 and 19 of each period at $0,8,16$, and $24 \mathrm{~h}$ after feeding for DM and particle size analysis. All samples were sieved in the American Society of Agriculture and Biological Engineers (ASABE) forage particle separator (ASABE, St. Joseph, MI), which can determine 6 particle fractions $(>26.9,>18.0,>8.98$, $>5.61,>1.65$, and $<1.65 \mathrm{~mm}$; screen diagonals; ASABE, 2007). Whole samples were then placed in a forcedair oven at $65^{\circ} \mathrm{C}$ for $48 \mathrm{~h}$ to determine DM content. Samples of forages, ground corn, and TMR were taken on d 18 and 9 of each period, composited by period and analyzed by Cumberland Valley Analytical Services Inc. (Hagerstown, MD) for CP (AOAC International, 2000), ADF (AOAC International, 2000), NDF (Van Soest et al., 1991), ash (AOAC International, 2000), NFC (Van Soest et al., 1991), and $\mathrm{NE}_{\mathrm{L}}$ (NRC, 2001). Starch and NDF contents of forages, ground corn, and TMR (at 0 and $24 \mathrm{~h}$ after feeding) were determined by drying in a forced-air oven at $65^{\circ} \mathrm{C}$ for $48 \mathrm{~h}$ and grinding (0.5- and 1.0-mm screen for starch and NDF, respectively; Wiley Mill, Arthur H. Thomas Co. Inc., Swedesboro, NJ). Starch was then analyzed via the procedure reported by Zanton and Heinrichs (2009) and NDF was analyzed using heat-stable $\alpha$-amylase and $\mathrm{Na}_{2} \mathrm{SO}_{3}$ according to Van Soest et al. (1991). Particle size distributions of forages and TMR were determined via sieving with the ASABE forage particle separator (ASABE, 2007). To determine particle size distributions of ground corn, samples were placed on a series of stacked sieves (sizes $0.15,0.425,0.60,0.85,1.18,1.70,2.36,3.35,4.75$, and $6.7 \mathrm{~mm}$; VWR, Arlington Heights, IL) contained in a Retsch AS 200 Control sieve shaker (Retsch GmbH, Haan, Germany) and were sieved for $10 \mathrm{~min}$ at 2.5$\mathrm{mm}$ amplitude. Particles retained on each sieve were then weighed to determine their proportion of total sample DM. Two procedures were used to calculate physically effective NDF (peNDF): $\operatorname{peNDF}_{8.98}=\%$ of particles $>8.98 \mathrm{~mm} \times \mathrm{NDF}$ of whole sample (similar to top 2 sieves of the Penn State Particle Separator; The Pennsylvania State University, University Park) and peNDF $_{1.65}=\%$ of particles $>1.65 \mathrm{~mm} \times \mathrm{NDF}$ of whole sample (similar to top 3 sieves of the Penn State Particle Separator; Kononoff et al., 2003a). Corn grain fermentability was determined via in situ bags incubated in quadruplicate in the rumen of 2 lactating cows (each cow incubated 2 bags of each sample for each time point) for $0.5,1,2,4,6,8,12,16,24$, and $48 \mathrm{~h}$. Approximately $7 \mathrm{~g}$ of each sample was sealed in a nylon bag $(10 \times 20 \mathrm{~cm}, 50-\mu \mathrm{m}$ pore size; Ankom Technology, Macedon, NY) attached to a string that was anchored to the rumen cannulas and weighted to locate the bags centrally in the rumen. After removal from the rumen, bags were rinsed in cold water by hand until water was almost clear. Bags were then dried in a forced-air oven at $65^{\circ} \mathrm{C}$ for $48 \mathrm{~h}$ and then weighed to determine the remaining DM content (Schwab et al., 2003).

\section{Milk Production}

Milk production was recorded daily and milk samples were taken on d 20 and 21 (4 consecutive milkings). Samples were collected and preserved using 2-bromo2-nitropropane-1,3-diol. Milk samples were analyzed for fat, true protein, lactose, MUN, and SCC by the Dairy One milk-testing laboratory (State College, PA) using 
infrared spectrophotometry (Foss 605B MilkoScan; Foss Electric A/S, Hillerød, Denmark).

\section{Statistical Analyses}

Statistical analysis was conducted using PROC MIXED of SAS (version 9.2; SAS Institute Inc., Cary, NC). Dependent variables were analyzed as a $4 \times 4$ Latin square design. All denominator degrees of freedom for $F$-tests were calculated according to Kenward and Roger (1997) and repeated measurements for ruminal $\mathrm{pH}, \mathrm{VFA}$, and $\mathrm{NH}_{3}$ concentrations and ground corn DM disappearance were analyzed using the first-order autoregressive covariance structure (Littell et al., 1998) as well as terms for time and interaction of treatment by time. Because of unequally spaced rumen sampling, the weighted mean daily $\mathrm{pH}, \mathrm{VFA}$, and $\mathrm{NH}_{3}$ concentrations were determined by calculating the area under the response curve according to the trapezoidal rule (Shipley and Clark, 1972). Area under the curve for the SARA thresholds of 5.8 and 5.5 were also calculated using the trapezoidal rule (Shipley and Clark, 1972). A selection index based on refusals was calculated for each of the 6 particle size fractions at 8,16 , and 24 $\mathrm{h}$ after feeding. This index was calculated as the actual intake of each fraction ( $Y_{i}$ to pan) expressed as a proportion of the expected intake. Expected intake of $Y_{i}$ equals intake multiplied by the fraction of $Y_{i}$ in the fed TMR (Leonardi and Armentano, 2003). Sorting indices were calculated using both the expected intake since time point 0 (cumulative) and the expected intake since the previous time point (interval). Values $>1.0$ indicate that cows were sorting for the particle fraction and values $<1.0$ indicate that cows were sorting against the particle fraction. The $95 \%$ confidence limits were used to determine if a selection index was significantly different from 1.0. Chewing behavior and meal criteria was analyzed using the procedure of Maulfair et al. (2010). All data are presented as least squares means and treatment effects are considered significant when $P \leq 0.05$ and a trend when $0.05<P \leq 0.15$. Means separation tests were conducted using the protected least significant differences procedure (PROC PDIFF), with significance at $P \leq 0.05$ unless otherwise stated.

\section{RESULTS AND DISCUSSION}

\section{Chemical Composition and Particle Size Distribution of Diets}

Particle size distributions and chemical compositions of forages used in this study are shown in Table 1. A large difference was observed in particle size distribution between LCS and SCS. When separated with the
ASABE particle separator, LCS had many more particles retained on $26.9-$ and $18.0-\mathrm{mm}$ screens $(P<0.01)$, equal particles on the $8.98-\mathrm{mm}$ screen, and many fewer particles on 5.61- and 1.65-mm screens and the pan than SCS. The approximate equivalency of Penn State Particle Separator fractions to the ASABE screens are as follows: top $(26.9+18.0 \mathrm{~mm})$, middle $(8.98 \mathrm{~mm})$, lower $(5.61+1.65 \mathrm{~mm})$, and pan (pan). The particle size distribution of alfalfa haylage was similar to SCS. Chemical compositions of the corn silages were similar and not practically different despite being statistically different for $\mathrm{DM}$ and $\mathrm{NE}_{\mathrm{L}}$. Sampling error may be responsible for the small differences seen between LCS and SCS, as they were taken from the same bag each day as a single batch, with part being rechopped as the only procedural difference. The peNDF measures were, as expected, very different between corn silages, but a much greater difference was observed for peNDF $_{8.98}$ than for peNDF ${ }_{1.65}$. The LCS was 1.81 and 1.15 times greater than SCS for peNDF 8.98 and peNDF 1.65 , respectively. The particle size distribution of the corn silage before bagging was analyzed by taking 5 samples evenly spaced over the length of the bag. It was determined that the process of bagging and ensiling corn silage altered its particle size distribution; before ensiling, the proportions retained on each sieve were $30.5 \pm 0.73$, $24.7 \pm 0.70,24.0 \pm 1.05,9.0 \pm 0.10,8.5 \pm 0.44$, and 3.4 $\pm 0.39 \%$ (mean \pm SEM) for the 26.9-, 18.0-, 8.98-, 5.61, 1.65-mm sieves, and pan, respectively. All particle fractions of the fresh forage were different from ensiled LCS $(P<0.05)$ except for the pan, which tended to be different $(P=0.06)$.

The particle size distributions, chemical compositions, and rates of disappearance for corn grains used in this study are shown in Table 2 . The particle size distributions of $\mathrm{CC}$ and $\mathrm{FC}$ were different at all 11 particle fractions. The greatest differences occurred at screen sizes $2.36 \mathrm{~mm}$ and larger, where CC had $67.4 \%$ and FC had $5.6 \%$ of particles retained, and at screen sizes 1.18 $\mathrm{mm}$ and smaller, where $\mathrm{CC}$ had $18.4 \%$ and FC had $78.2 \%$ of particles retained. The chemical compositions of $\mathrm{CC}$ and $\mathrm{FC}$ were similar and not practically different despite being statistically different in DM and CP content. The rates of DM disappearance of $\mathrm{CC}$ and FC were different at every time point except $48 \mathrm{~h}(P$ $=0.15)$. The greatest differences between $\mathrm{CC}$ and $\mathrm{FC}$ were in the first $2 \mathrm{~h}$ of incubation, where FC had about 2.1 times more DM disappearance than $\mathrm{CC}(P<0.01)$. The disappearance of FC continued to be greater than $\mathrm{CC}$ at each time point (except $48 \mathrm{~h}$ ), but the magnitude of differences between them decreased with increasing incubation time. Particle size distributions and chemical compositions of treatment TMR are shown in Table 3. Varying FPS and RFC altered the particle 
Table 1. Chemical compositions and particle size distributions determined with the American Society of Agriculture and Biological Engineers (ASABE) particle separator (ASABE, St. Joseph, MI) for alfalfa haylage and long and short corn silage

\begin{tabular}{|c|c|c|c|c|c|}
\hline \multirow[b]{2}{*}{ Item } & \multirow{2}{*}{$\begin{array}{c}\text { Alfalfa } \\
\text { haylage }\end{array}$} & \multicolumn{4}{|c|}{ Corn silage } \\
\hline & & Long & Short & $\mathrm{SEM}^{1}$ & $P$-value ${ }^{1}$ \\
\hline \multicolumn{6}{|c|}{ Particle size, ${ }^{2}$ as-fed $\%$ retained } \\
\hline $26.9 \mathrm{~mm}$ & 1.9 & 13.2 & 0.9 & 0.64 & $<0.01$ \\
\hline $18.0 \mathrm{~mm}$ & 5.7 & 31.0 & 13.4 & 0.60 & $<0.01$ \\
\hline $8.98 \mathrm{~mm}$ & 25.2 & 28.5 & 28.7 & 1.30 & 0.90 \\
\hline $5.61 \mathrm{~mm}$ & 23.8 & 13.5 & 22.1 & 2.48 & 0.08 \\
\hline $1.65 \mathrm{~mm}$ & 32.2 & 11.7 & 25.8 & 1.47 & $<0.01$ \\
\hline Pan & 11.1 & 2.1 & 9.0 & 2.34 & 0.08 \\
\hline \multicolumn{6}{|c|}{ Composition, $\%$ of DM } \\
\hline $\mathrm{DM}$ & 47.7 & 39.3 & 40.6 & 1.18 & $<0.01$ \\
\hline $\mathrm{CP}$ & 18.8 & 8.7 & 8.5 & 0.07 & 0.19 \\
\hline $\mathrm{ADF}$ & 36.0 & 20.7 & 19.0 & 0.61 & 0.09 \\
\hline $\mathrm{NDF}$ & 45.8 & 34.8 & 32.6 & 0.85 & 0.12 \\
\hline $\operatorname{peNDF}_{8.98}{ }^{3}$ & 15.1 & 25.4 & 14.0 & 0.86 & $<0.01$ \\
\hline $\operatorname{peNDF}_{1.65}{ }^{4}$ & 40.8 & 34.1 & 29.6 & 1.24 & $<0.01$ \\
\hline Ash & 10.3 & 3.2 & 3.3 & 0.12 & 0.59 \\
\hline NFC & 24.0 & 50.1 & 52.8 & 0.92 & 0.12 \\
\hline Starch & 0.67 & 40.7 & 41.2 & 1.88 & 0.85 \\
\hline $\mathrm{NE}_{\mathrm{L}}, \mathrm{Mcal} / \mathrm{kg}$ & 1.36 & 1.73 & 1.79 & 0.01 & 0.02 \\
\hline
\end{tabular}

${ }^{1}$ Associated with corn silages.

${ }^{2}$ Approximate equivalency to Penn State Particle Separator (The Pennsylvania State University, University Park): top sieve $(26.9+18.0 \mathrm{~mm})$, middle sieve $(8.98 \mathrm{~mm})$, lower sieve $(5.61+1.65 \mathrm{~mm})$, and pan $(\operatorname{pan})$.

${ }^{3}$ Physically effective $\mathrm{NDF}_{8.98}=\%$ of particles $>8.98 \mathrm{~mm} \times \mathrm{NDF}$ of whole sample.

${ }^{4}$ Physically effective $\mathrm{NDF}_{1.65}=\%$ of particles $>1.65 \mathrm{~mm} \times \mathrm{NDF}$ of whole sample.

size distribution of diets. The 2 largest fractions were increased with increasing FPS, whereas the 4 other fractions were affected by both FPS and RFC. Increasing FPS increased particles retained on the 26.0-, 18.0-, and $8.98-\mathrm{mm}$ sieves and decreased particles retained on the 5.61- and $1.65-\mathrm{mm}$ sieves and the pan. Increasing RFC decreased particles retained on the 8.98- and 5.61$\mathrm{mm}$ sieves and increased particles on the $1.65-\mathrm{mm}$ sieve and pan. Chemical compositions of TMR were similar and not practically different. The $\mathrm{CP}, \mathrm{NDF}$, forage NDF, and starch content of TMR were approximately $16.4,31.9,21.4$, and $31.0 \%$ of $\mathrm{DM}$, respectively. The peNDF measures were affected by both FPS and RFC effects; increasing FPS and decreasing RFC increased both peNDF measures. The greatest variation occurred with peNDF ${ }_{898}$, where LC was 2.20 times greater than SF (14.1 vs. $6.4 \%$ ). The LC diet was only 1.33 times greater than $\mathrm{SF}$ for $\mathrm{peNDF}_{1.65}(27.9$ vs. $21.0 \%)$.

\section{Chewing Behavior}

Ruminating minutes per day were shown to increase with $\operatorname{RFC}(P=0.03)$ but were not affected by FPS; this increase was much larger for diets containing short FPS (Table 4). The ability of RFC to increase ruminating time may be counterintuitive, but this result was also seen by Krause et al. (2002b). Those authors determined that increasing RFC, by replacing dry cracked shelled corn with high-moisture corn in an alfalfa silage diet, tended to increase ruminating minutes per day and increased ruminating minutes per kilogram of NDF intake. Krause et al. (2002b) suggested that because forage should be the only diet component that could stimulate rumination, the increase in ruminating activity was a result of an adaptive response by the animals to increased RFC to attenuate low ruminal $\mathrm{pH}$ via increased saliva secretion. Daily ruminating times varied from 354.7 to $400.2 \mathrm{~min} / \mathrm{d}$ across treatments. Eating minutes per day, in contrast to ruminating minutes per day, were not affected by RFC but increased with FPS $(P=0.01)$. The effect of increased eating time with longer FPS is well known in the literature (Bailey, 1961; Beauchemin et al., 2008). Finally, total chewing time per day was not significantly affected by FPS or $\mathrm{RFC}$, but an increase in either tended to increase total chewing minutes per day. These results conflict with those reported by Krause et al. (2002b) who found that increasing FPS increased both eating and ruminating minutes per day and that increasing RFC decreased eating minutes per day while increasing rumination minutes per day. These differences in the results might be related to how RFC was increased in the 2 studies; in the current study, it was increased by decreasing grind size of dry corn grain, whereas Krause et al. (2002b) increased RFC by replacing dry cracked corn with high-moisture corn. However, Krause and Combs 
Table 2. Chemical compositions, particle size distributions, and rates of disappearance determined via in situ incubation for dry cracked and dry fine ground $\operatorname{corn}^{1}$

\begin{tabular}{lcccc}
\hline Item & Cracked & Fine ground & SEM & $P$-value \\
\hline Particle size, as-fed \% retained & & & & \\
$6.70 \mathrm{~mm}$ & 2.2 & 0.0 & 0.18 & $<0.01$ \\
$4.75 \mathrm{~mm}$ & 10.0 & 0.1 & 1.38 & $<0.01$ \\
$3.35 \mathrm{~mm}$ & 29.7 & 0.3 & 1.51 & $<0.01$ \\
$2.36 \mathrm{~mm}$ & 25.5 & 5.2 & 1.29 & $<0.01$ \\
$1.70 \mathrm{~mm}$ & 14.2 & 16.2 & 1.22 & 0.05 \\
$1.18 \mathrm{~mm}$ & 6.5 & 17.7 & 0.54 & $<0.01$ \\
$0.85 \mathrm{~mm}$ & 3.2 & 13.3 & 0.29 & $<0.01$ \\
$0.60 \mathrm{~mm}$ & 2.7 & 11.0 & 0.33 & $<0.01$ \\
$0.425 \mathrm{~mm}$ & 2.0 & 11.4 & 0.80 & $<0.01$ \\
$0.15 \mathrm{~mm}$ & 3.0 & 22.3 & 0.78 & $<0.01$ \\
Pan & 1.0 & 2.5 & 0.22 & 0.01 \\
Composition, \% of DM & & & & \\
DM & 90.3 & 88.3 & 0.36 & 0.03 \\
$\mathrm{CP}$ & 8.8 & 9.4 & 0.16 & 0.04 \\
ADF & 5.1 & 4.4 & 0.38 & 0.27 \\
NDF & 11.3 & 11.1 & 0.52 & 0.77 \\
Ash & 1.4 & 1.6 & 0.12 & 0.31 \\
NFC & 75.1 & 74.7 & 0.94 & 0.75 \\
NE, Mcal/kg & 1.96 & 1.96 & 0.00 & 1.00 \\
In situ residual, \% & & & & \\
$0.5 \mathrm{~h}$ & 17.7 & 36.1 & 2.96 & $<0.01$ \\
$1.0 \mathrm{~h}$ & 18.4 & 38.3 & 2.96 & $<0.01$ \\
$2.0 \mathrm{~h}$ & 19.0 & 42.0 & 2.96 & $<0.01$ \\
$4.0 \mathrm{~h}$ & 27.6 & 48.8 & 2.96 & $<0.01$ \\
$6.0 \mathrm{~h}$ & 34.2 & 58.2 & 2.96 & $<0.01$ \\
$8.0 \mathrm{~h}$ & 41.9 & 65.8 & 2.96 & $<0.01$ \\
$12.0 \mathrm{~h}$ & 56.1 & 76.9 & 2.96 & $<0.01$ \\
$24.0 \mathrm{~h}$ & 59.1 & 83.8 & 2.96 & $<0.01$ \\
$48.0 \mathrm{~h}$ & 76.4 & 92.0 & 2.96 & $<0.01$ \\
\hline & 90.7 & 96.2 & 2.96 & 0.15 \\
\hline
\end{tabular}

${ }^{1}$ Nylon bags were incubated in quadruplicate in the rumen of 2 lactating cows (each cow incubated 2 bags of each sample for each time point).

(2003) found that increasing FPS increased both eating and ruminating time and that RFC did not affect eating or ruminating and their study altered RFC the same way as the study of Krause et al. (2002b).

\section{Ruminal Characteristics}

Daily weighted mean, minimum, and maximum ruminal $\mathrm{pH}$ did not differ by varying FPS or RFC, although a trend was observed for weighted mean and maximum $\mathrm{pH}$ to increase with FPS and for minimum $\mathrm{pH}$ to decrease with increasing RFC (Table 5). Increasing FPS likely affected ruminal $\mathrm{pH}$ through the increased eating time it caused, which has been shown to increase saliva secretion (Bailey, 1961; Beauchemin et al., 2008) and increase ruminal buffering. The increased rumination time caused by increasing RFC did not have the same positive effect of increased eating time on ruminal $\mathrm{pH}$, as ruminal $\mathrm{pH}$ actually tended to decrease with increasing RFC. This likely occurred because either increased saliva secretion was unable to compensate for increased $\mathrm{RFC}$ or increasing eating time was more effective at elevating saliva secretion than increasing ruminating time. These results conflict with several studies that showed that increasing RFC decreased mean ruminal pH (Yang et al., 2001; Krause et al., 2002b; Krause and Combs, 2003). Perhaps the methods of increasing RFC in these studies (replacing dry cracked with highmoisture corn or replacing coarsely rolled with flatly rolled barley grain) were more effective than the one used in the current study (replacing dry cracked with fine ground corn). Two of these same studies found that FPS had no effect on mean ruminal $\mathrm{pH}$ (Yang et al., 2001; Krause and Combs, 2003) and 1 found that ruminal pH increased with FPS (Krause et al., 2002b). Concentrations of $\mathrm{NH}_{3}$ and lactate did not differ by altering FPS and RFC, although there tended to be an interaction of FPS and RFC for weighted mean $\mathrm{NH}_{3}$ concentration because $\mathrm{NH}_{3}$ increased with RFC for the short diets but decreased with increasing RFC for the long diets. Weighted mean concentrations of VFA were also not different when changing FPS or RFC, although several trends were observed. Increasing FPS tended to decrease acetate, butyrate, and isobutyrate concentration, whereas increasing RFC tended to increase valerate and decrease the acetate-to-propionate ratio. 
Table 3. Chemical composition and particle size distributions determined with the American Society of Agriculture and Biological Engineers (ASABE) particle separator (ASABE, St. Joseph, MI) for TMR varying in forage particle size (FPS) and ruminally fermentable carbohydrates $(\mathrm{RFC})$

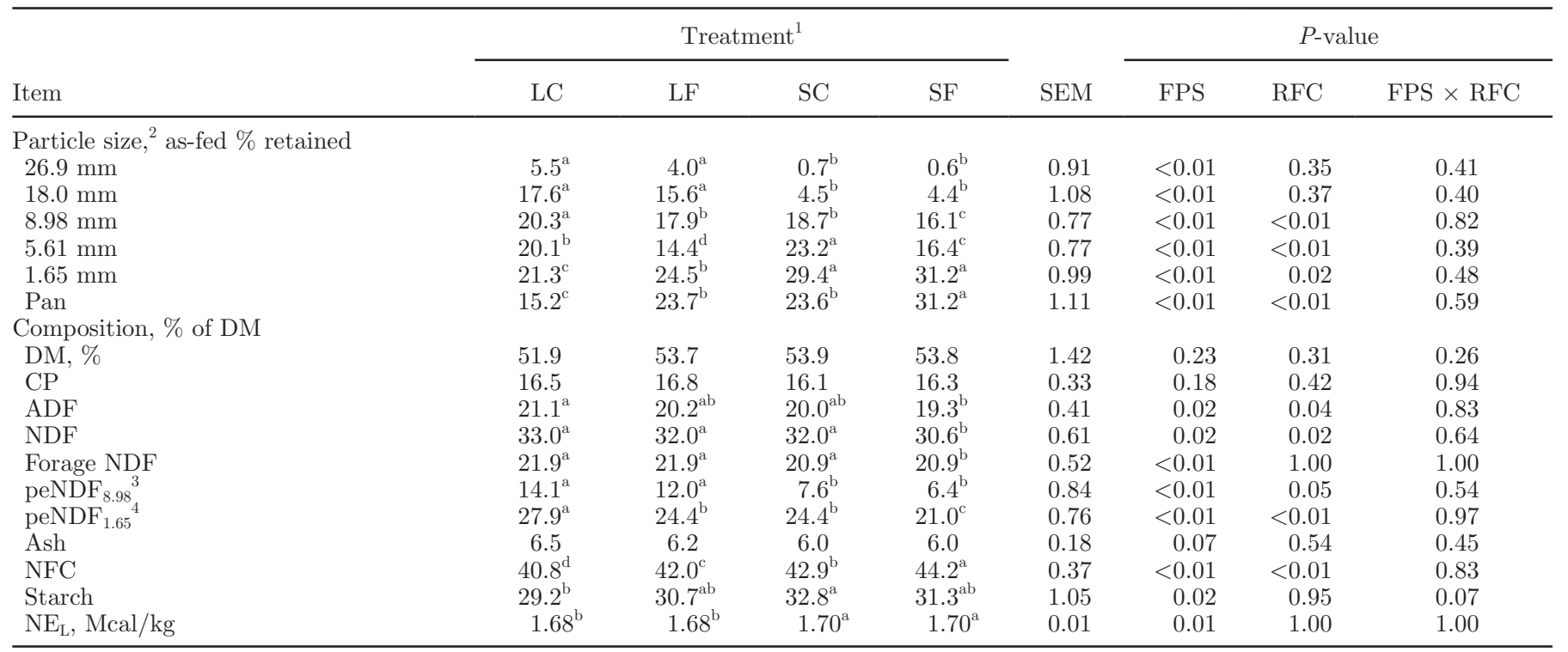

${ }^{\mathrm{a}-\mathrm{d}}$ Means within a row with different superscripts differ $(P \leq 0.05)$.

${ }^{1} \mathrm{LC}=$ long corn silage and dry cracked corn; LF = long corn silage and dry fine ground corn; SC = short corn silage and dry cracked corn; SF $=$ short corn silage and dry fine ground corn.

${ }^{2}$ Approximate equivalency to Penn State Particle Separator (The Pennsylvania State University, University Park): top sieve (26.9 + 18.0 mm), middle sieve $(8.98 \mathrm{~mm})$, lower sieve $(5.61+1.65 \mathrm{~mm})$, and pan (pan).

${ }^{3}$ Physically effective $\mathrm{NDF}_{8.98}=\%$ of particles $>8.98 \mathrm{~mm} \times \mathrm{NDF}$ of whole sample.

${ }^{4}$ Physically effective $\mathrm{NDF}_{1.65}=\%$ of particles $>1.65 \mathrm{~mm} \times \mathrm{NDF}$ of whole sample.

Also, FPS and RFC tended to interact for propionate as it increased with RFC for short-FPS diets but did not change for long-FPS diets. Finally, ruminal digesta weight and volume were not affected by FPS or RFC.

\section{Intakes, Refusals, and Ration Sorting}

The TMR refusals were analyzed for NDF and starch at $24 \mathrm{~h}$ after feeding and for particle size distribution at $0,8,16$, and $24 \mathrm{~h}$ after feeding. The TMR concentrations of starch and NDF are shown in Figures 1 and 2, respectively. Starch concentration was lower $24 \mathrm{~h}$ after feeding, especially for diets that contained long FPS, whereas NDF concentrations tended to be increased at $24 \mathrm{~h}$ after feeding. This indicates that cows were generally sorting for concentrates and against fiber in all treatments. This theory is reinforced by the particle size distribution of TMR over time (Figure 3 ). Particles retained on the 26.9- and 18.0-mm (data not shown) sieves showed very similar patterns over the course of the day for each diet; these particles increased in diets containing LCS with time after feeding and did not change in diets containing SCS. These longer size particles were almost exclusively forage, whereas the shortest fractions were primarily concentrate. The particles retained on the 8.98- and 5.61-mm sieves generally did not change over time for any diets, and the amount of particles retained on these sieves relative to

Table 4. Effect of feeding TMR varying in forage particle size (FPS) and ruminally fermentable carbohydrates (RFC) on chewing behavior

\begin{tabular}{|c|c|c|c|c|c|c|c|c|}
\hline \multirow[b]{2}{*}{ Item, $\min / \mathrm{d}$} & \multicolumn{4}{|c|}{ Treatment $^{1}$} & \multirow[b]{2}{*}{ SEM } & \multicolumn{3}{|c|}{$P$-value } \\
\hline & $\mathrm{LC}$ & $\mathrm{LF}$ & $\mathrm{SC}$ & $\mathrm{SF}$ & & FPS & $\mathrm{RFC}$ & $\mathrm{FPS} \times \mathrm{RFC}$ \\
\hline Ruminating & $373.0^{\mathrm{ab}}$ & $389.0^{\mathrm{ab}}$ & $354.7^{\mathrm{b}}$ & $400.2^{\mathrm{a}}$ & 18.0 & 0.80 & 0.03 & 0.30 \\
\hline Eating & $200.2^{\mathrm{ab}}$ & $206.6^{\mathrm{a}}$ & $178.0^{\mathrm{ab}}$ & $174.8^{\mathrm{b}}$ & 11.7 & 0.01 & 0.88 & 0.65 \\
\hline Total chewing & $573.2^{\mathrm{ab}}$ & $595.6^{\mathrm{a}}$ & $532.7^{\mathrm{b}}$ & $575.1^{\mathrm{ab}}$ & 23.4 & 0.14 & 0.11 & 0.62 \\
\hline
\end{tabular}

a,b Means within a row with different superscripts differ $(P \leq 0.05)$.

${ }^{1} \mathrm{LC}=$ long corn silage and dry cracked corn; $\mathrm{LF}=$ long corn silage and dry fine ground corn; $\mathrm{SC}=$ short corn silage and dry cracked corn; SF $=$ short corn silage and dry fine ground corn. 
Table 5. Effect of feeding TMR varying in forage particle size (FPS) and ruminally fermentable carbohydrates (RFC) on rumen fermentation

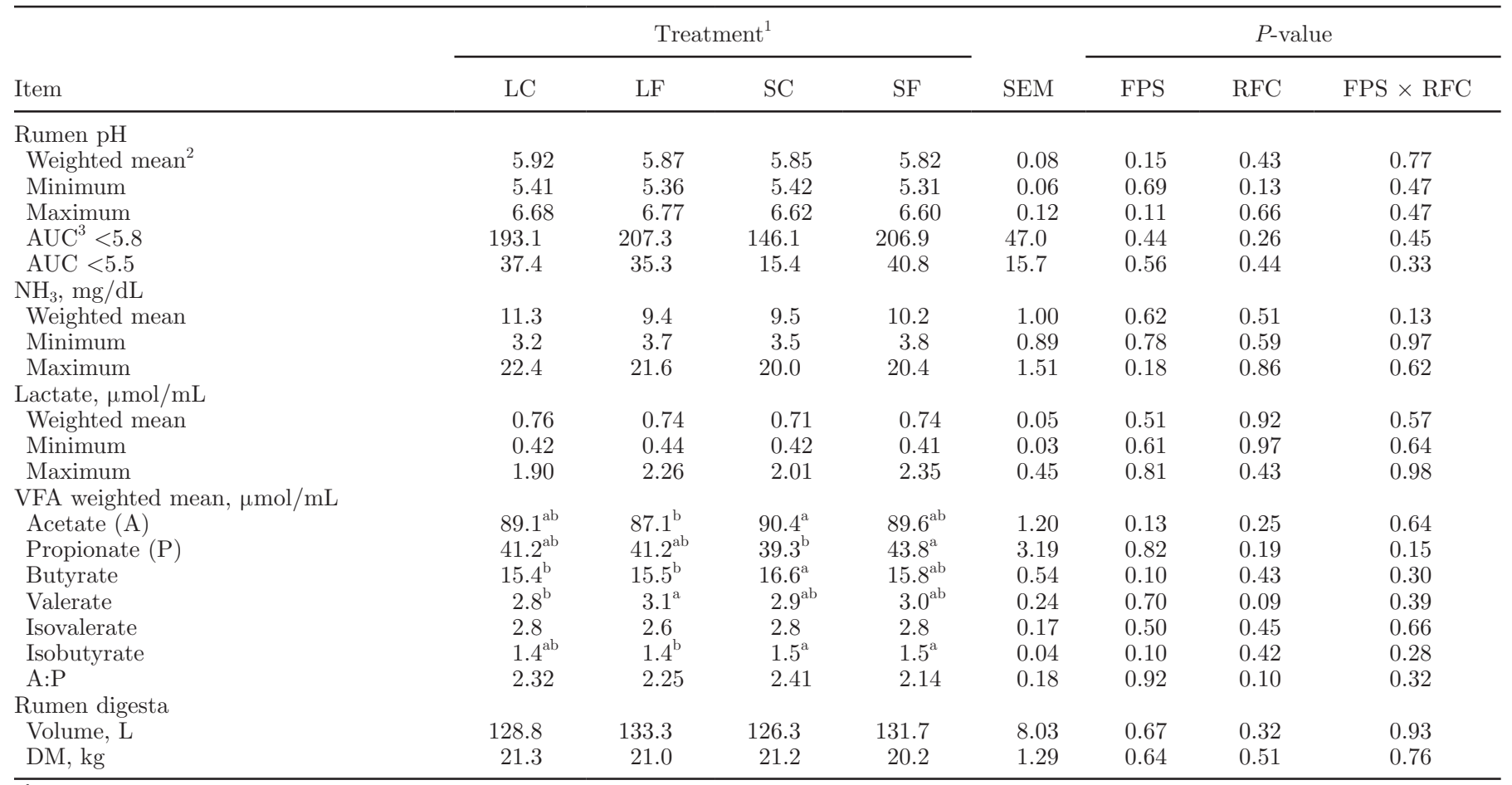

${ }_{\mathrm{a}, \mathrm{b}}$ Means within a row with different superscripts differ $(P \leq 0.10)$.

${ }^{1} \mathrm{LC}=$ long corn silage and dry cracked corn; LF = long corn silage and dry fine ground corn; SC = short corn silage and dry cracked corn; SF $=$ short corn silage and dry fine ground corn.

${ }^{2}$ Weighted averages were determined by calculating the area under the response curve according to the trapezoidal rule (Shipley and Clark, 1972)

${ }^{3} \mathrm{AUC}=$ area under curve, $\mathrm{pH}$ units $\times \mathrm{min} / \mathrm{d}$ [area below $\mathrm{pH}$ threshold (5.5 or 5.8) and above $\mathrm{pH}$ profiles of cows].

each diet remained constant as well. Particles retained on the 1.65-mm sieve decreased in diets containing LCS and did not change in diets containing SCS, whereas particles retained on the pan decreased in all diets over a 24 -h period. These results show that cattle were effectively altering TMR composition (chemical and physical) through sorting, and that cows were able to sort to a higher degree on the long-FPS diets.

Ration sorting was also evaluated via selection indices at 8,16 , and $24 \mathrm{~h}$ after feeding. Cumulative selection indices are shown in Table 6 and represent actual consumption of each particle fraction at various time points compared with estimated consumption if cows consumed all particles in the proportion offered in the original TMR. These results indicate that ration sorting was affected by FPS for the 26.9-mm particle fraction $(P<0.01)$ and by RFC for the 8.98 - and $5.61-\mathrm{mm}$ particle fractions $(P<0.01)$. Generally, greater sorting activity was observed at earlier time points and longer particle fractions; no selection index was significantly different from 1.0 at $24 \mathrm{~h}$ after feeding for the 3 shortest particle fractions. When significantly affecting selection indices, increasing both FPS and RFC increased sorting activity, but the changes and degrees of sorting were

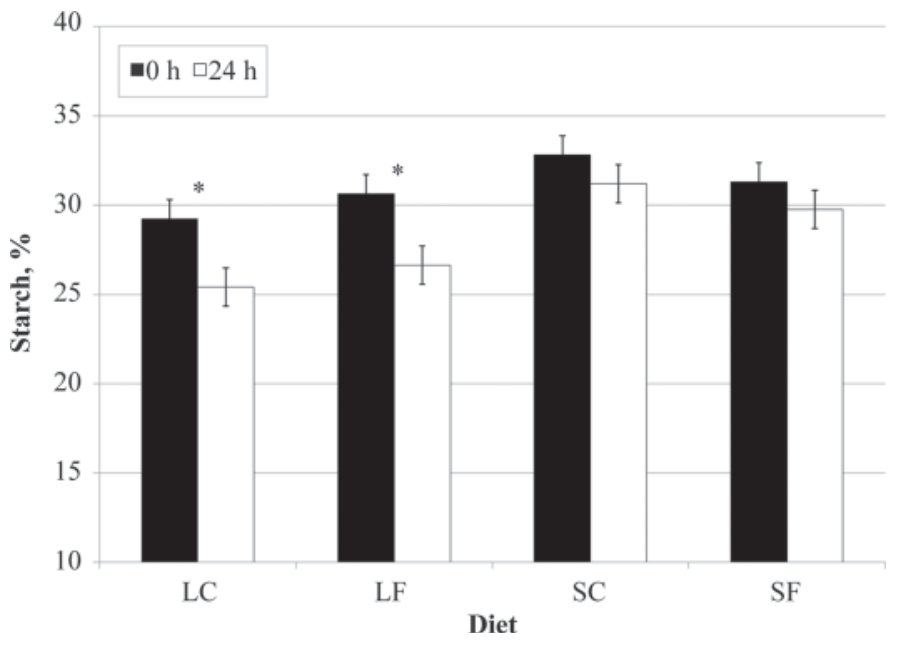

Figure 1. Effect of feeding TMR varying in forage particle size (FPS) and ruminally fermentable carbohydrates (RFC) on starch concentration at 0 and $24 \mathrm{~h}$ after feeding. $\mathrm{LC}=$ long corn silage and dry cracked corn; $\mathrm{LF}=$ long corn silage and dry fine ground corn; $\mathrm{SC}=$ short corn silage and dry cracked corn; $\mathrm{SF}=$ short corn silage and dry fine ground corn. ${ }^{*}$ indicates time effect: $P \leq 0.05$; overall time effect: $P<0.01$. Error bars represent the standard error for each time point. 


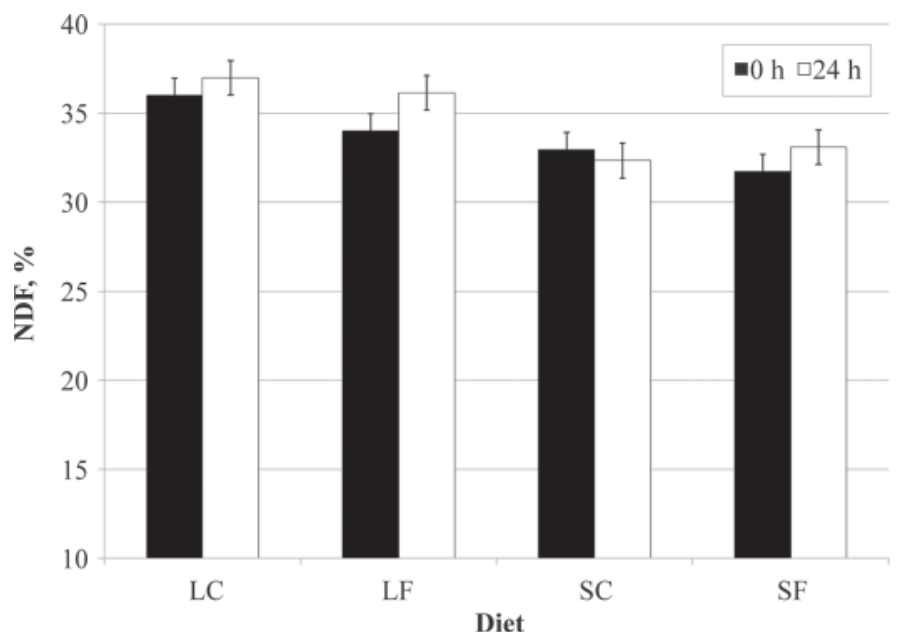

Figure 2. Effect of feeding TMR varying in forage particle size (FPS) and ruminally fermentable carbohydrates (RFC) on NDF concentration at 0 and $24 \mathrm{~h}$ after feeding. $\mathrm{LC}=$ long corn silage and dry cracked corn; LF = long corn silage and dry fine ground corn; $\mathrm{SC}=$ short corn silage and dry cracked corn; $\mathrm{SF}=$ short corn silage and dry fine ground corn; overall time effect: $P=0.15$. Error bars represent the standard error for each time point.

relatively small. Selection indices were also analyzed on an interval basis, which compared actual consumption of each particle fraction at various time points to estimated consumption if cows consumed all particles in the proportion found in TMR at the previous time point (Table 7). The interval method allows for a clearer view of how sorting changed throughout the day. For example, cows on the LC diet were sorting against particles retained on the $1.65-\mathrm{mm}$ sieve during the first $8 \mathrm{~h}$ of the day, but then sorted for these particles during the last $16 \mathrm{~h}$ of the day. Using this method, FPS was much more likely to affect ration sorting than RFC. As the day progressed, cows on all treatments increased their sorting against particles retained on the $18.0-\mathrm{mm}$ sieve and generally the $8.98-\mathrm{mm}$ sieve. Cows being fed diets that contained LCS increased their sorting for particles retained on the 5.61- and 1.65-mm sieves, and the pan as time after feeding increased. Clearly ration sorting was occurring in all treatments and at various times after feeding, but not to as great a degree as found in other studies (Maulfair et al., 2011). The feed composition and chemical analysis of the various fractions were not analyzed in this study.

A significant interaction was observed between FPS and RFC for DMI $(P<0.01$; Table 8$)$. Voluntary DMI decreased with increasing FPS when the diet included low RFC and did change when the diet included high RFC; DMI increased with RFC for the long diets $(P<$ $0.05)$ and did not change with RFC on the short diets. Effects of FPS and RFC on DMI have been variable in the literature: DMI increased with increasing RFC and
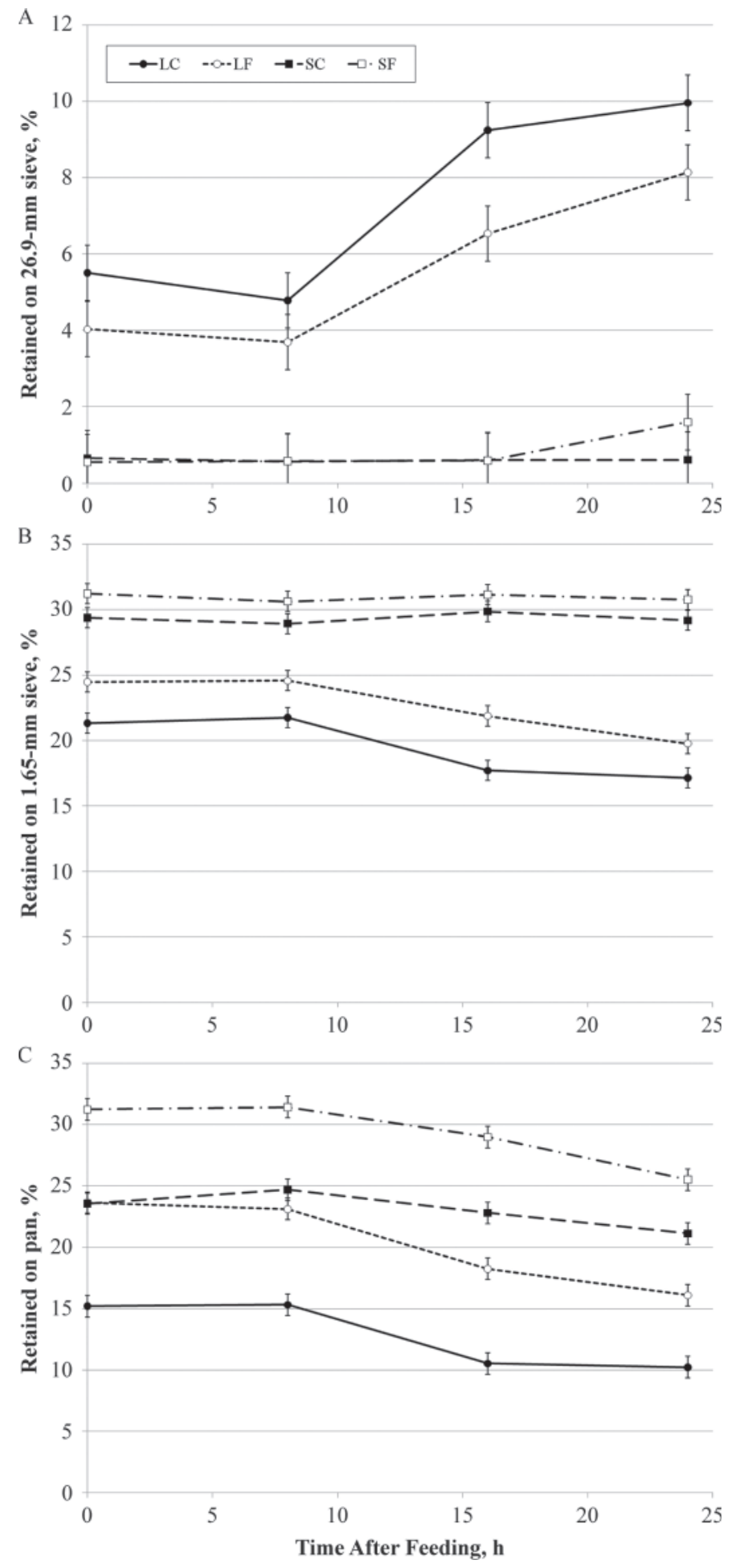

Figure 3. Effect of feeding TMR varying in forage particle size (FPS) and ruminally fermentable carbohydrates (RFC) on TMR particle fractions $>26.9 \mathrm{~mm}(\mathrm{~A}),>1.65 \mathrm{~mm}(\mathrm{~B})$, and pan (C) at $0,8,16$, and $24 \mathrm{~h}$ after feeding. $\mathrm{LC}=$ long corn silage and dry cracked corn; $\mathrm{LF}$ $=$ long corn silage and dry fine ground corn; $\mathrm{SC}=$ short corn silage and dry cracked corn; $\mathrm{SF}=$ short corn silage and dry fine ground corn. Error bars represent the standard error for each time point. 
Table 6. Effect of feeding TMR varying in forage particle size (FPS) and ruminally fermentable carbohydrates (RFC) on cumulative selection indices $^{1}$ for various particle fractions

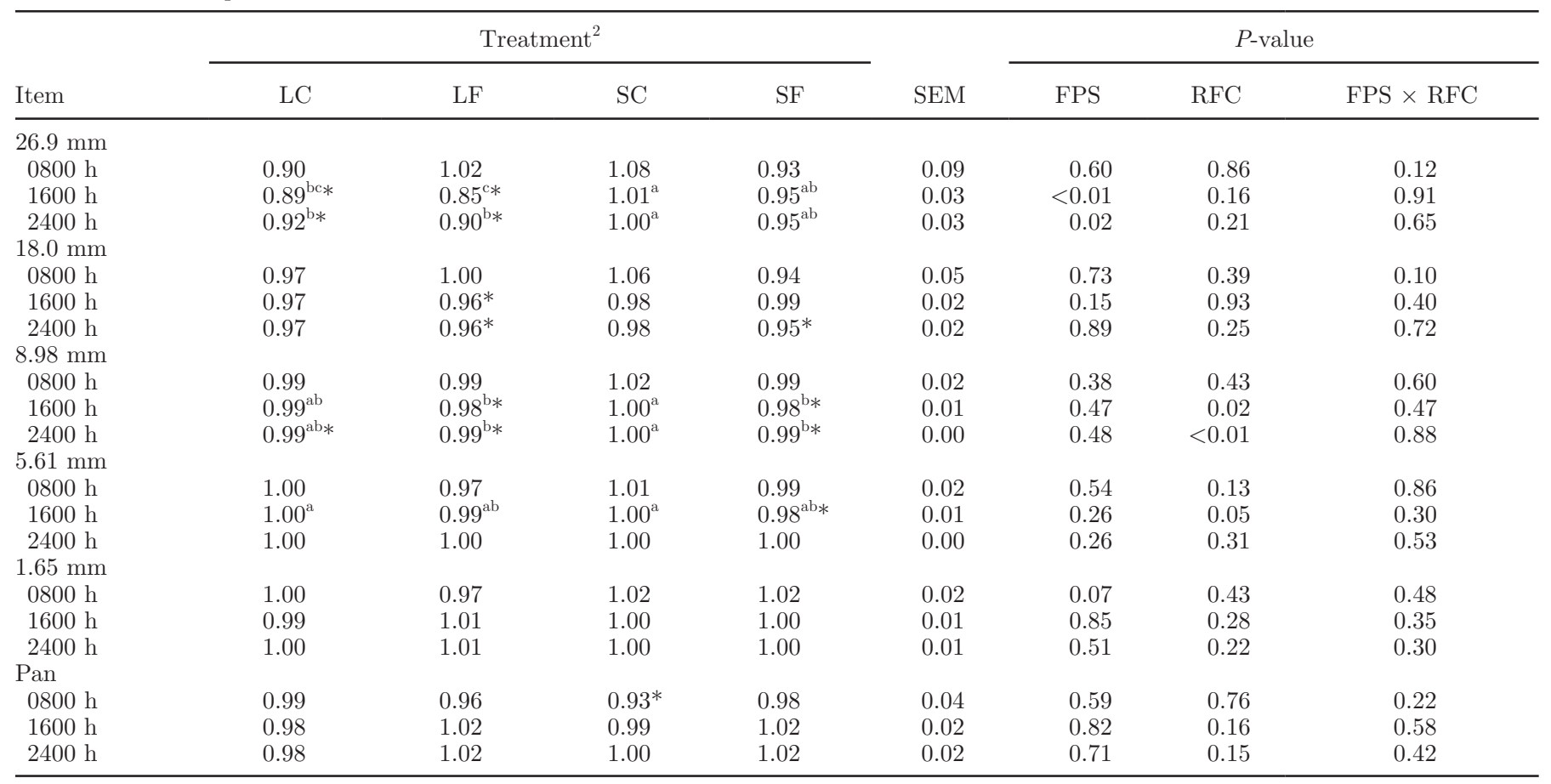

${ }^{\mathrm{a}-\mathrm{c}}$ Means within a row with different superscripts differ $(P \leq 0.05)$.

${ }^{1}$ Values of 1.00 indicate no sorting, values $<1.00$ indicate sorting against, and values $>1.00$ indicate sorting for.

${ }^{2} \mathrm{LC}=$ long corn silage and dry cracked corn; LF = long corn silage and dry fine ground corn; SC = short corn silage and dry cracked corn; SF = short corn silage and dry fine ground corn; approximate equivalency to Penn State Particle Separator (The Pennsylvania State University, University Park): top sieve $(26.9+18.0 \mathrm{~mm})$, middle sieve $(8.98 \mathrm{~mm})$, lower sieve $(5.61+1.65 \mathrm{~mm})$, and pan (pan).

*Sorting index is significantly different from 1.00 based on a $95 \%$ confidence limit.

was not affected by FPS in the study of Yang et al. (2001), DMI decreased with increasing RFC and was not affected by FPS in the study of Krause et al. (2002a), and DMI decreased with increasing RFC and increased with increasing FPS in the study of Krause and Combs (2003). Total NDF intake was not affected by FPS or RFC but starch intake was affected by both. Daily starch intake followed the same pattern of interaction that was found with DMI, and these differences were possibly a result of DMI variations. Daily intakes of each particle fraction are also shown in Tables 6 to 8. Intakes of all particle fractions, except $8.98 \mathrm{~mm}$, were affected by FPS, and RFC affected intakes of particle fractions $8.98 \mathrm{~mm}$ and smaller. Increasing FPS increased intake of particles retained on the 26.9- and $18.0-\mathrm{mm}$ sieves and decreased intake of particles retained on the 5.61and 1.65-mm sieves, and pan. Increasing RFC decreased intake of particles retained on the 8.98- and 5.61-mm sieves and increased intake of particles retained on the $1.65-\mathrm{mm}$ sieve and pan. These differences in particle fraction intakes are representative of the differences in their proportions in the offered TMR, indicating that ration sorting was not sufficient to cause differences between the consumed and offered rations.

The percentage of total daily intake consumed by 8 and $16 \mathrm{~h}$ after feeding was determined and is also shown in Table 8. Cows on the longer FPS treatments had consumed a greater percentage of their daily intakes at both 8 and $16 \mathrm{~h}$ after feeding compared with cows fed shorter FPS: 62.5 versus $54.6 \%$ and 92.1 versus $86.6 \%$ of total DMI for long and short FPS treatments at 8 and $16 \mathrm{~h}$ after feeding, respectively. This is somewhat surprising as it has been shown that increasing FPS decreases eating rate (Bailey, 1961; Beauchemin et al., 2008). Finally, feed refusal rate was not different among treatments and was successfully managed to a rate of $10.1 \%$ as planned.

\section{Milk Yield and Composition}

Milk yield and composition data are reported in Table 9. Milk yield was not influenced by FPS but was increased with RFC and averaged $43.5 \mathrm{~kg} / \mathrm{d}$ across treatments. Although increasing RFC increased milk 
Table 7. Effect of feeding TMR varying in forage particle size (FPS) and ruminally fermentable carbohydrates (RFC) on interval selection indices ${ }^{1}$ for various particle fractions

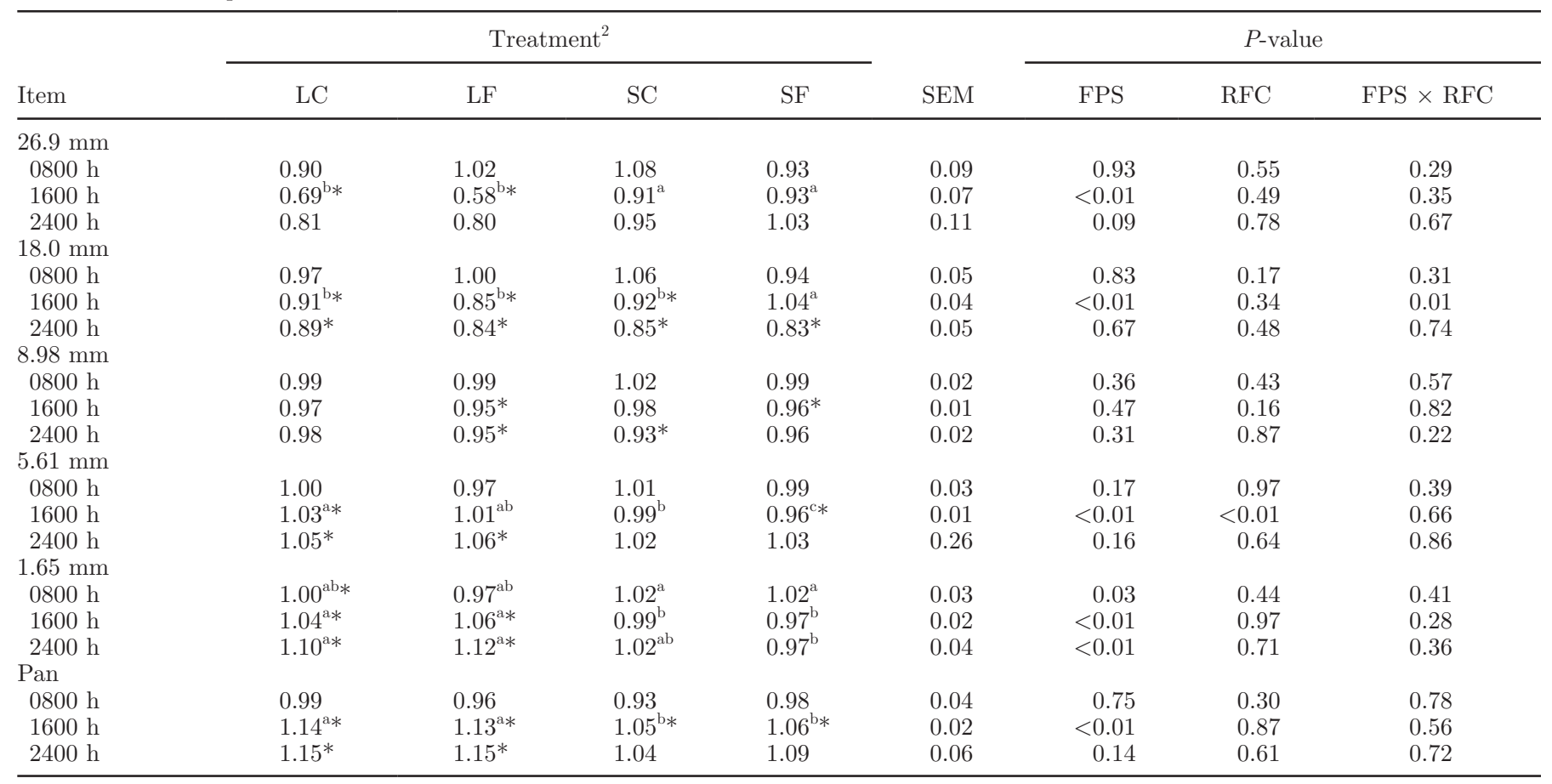

${ }^{\mathrm{a}-\mathrm{c}}$ Means within a row with different superscripts differ $(P \leq 0.05)$.

${ }^{1}$ Values of 1.00 indicate no sorting, values $<1.00$ indicate sorting against, and values $>1.00$ indicate sorting for.

${ }^{2} \mathrm{LC}=$ long corn silage and dry cracked corn; LF = long corn silage and dry fine ground corn; SC = short corn silage and dry cracked corn; SF $=$ short corn silage and dry fine ground corn; approximate equivalency to Penn State Particle Separator (The Pennsylvania State University, University Park): top sieve $(26.9+18.0 \mathrm{~mm})$, middle sieve $(8.98 \mathrm{~mm})$, lower sieve $(5.61+1.65 \mathrm{~mm})$, and pan (pan).

*Sorting index is significantly different from 1.00 based on a $95 \%$ confidence limit.

Table 8. Effect of feeding TMR varying in forage particle size (FPS) and ruminally fermentable carbohydrates (RFC) on daily DM, NDF, starch, and particle fraction intake

\begin{tabular}{|c|c|c|c|c|c|c|c|c|}
\hline \multirow[b]{2}{*}{ Item, kg } & \multicolumn{4}{|c|}{ Treatment $^{1}$} & \multirow[b]{2}{*}{ SEM } & \multicolumn{3}{|c|}{$P$-value } \\
\hline & $\mathrm{LC}$ & $\mathrm{LF}$ & $\mathrm{SC}$ & $\mathrm{SF}$ & & FPS & $\mathrm{RFC}$ & $\mathrm{PFS} \times \mathrm{RFC}$ \\
\hline Starch & $8.2^{\mathrm{b}}$ & $9.6^{\mathrm{a}}$ & $10.2^{\mathrm{a}}$ & $9.8^{\mathrm{a}}$ & 0.36 & $<0.01$ & 0.06 & $<0.01$ \\
\hline \multicolumn{9}{|c|}{ Particle fraction ${ }^{2}$} \\
\hline $26.9 \mathrm{~mm}$ & $1.43^{\mathrm{a}}$ & $1.14^{\mathrm{a}}$ & $0.21^{\mathrm{b}}$ & $0.14^{\mathrm{b}}$ & 0.13 & $<0.01$ & 0.16 & 0.36 \\
\hline $5.61 \mathrm{~mm}$ & $5.67^{\mathrm{b}}$ & $4.42^{\mathrm{d}}$ & $7.20^{\mathrm{a}}$ & $5.10^{\mathrm{c}}$ & 0.19 & $<0.01$ & $<0.01$ & $<0.01$ \\
\hline $1.65 \mathrm{~mm}$ & $6.10^{\mathrm{d}}$ & $7.63^{\mathrm{c}}$ & $9.11^{\mathrm{b}}$ & $9.76^{\mathrm{a}}$ & 0.29 & $<0.01$ & $<0.01$ & 0.04 \\
\hline Pan & $4.45^{\mathrm{c}}$ & $7.49^{\mathrm{b}}$ & $7.30^{\mathrm{b}}$ & $9.93^{\mathrm{a}}$ & 0.29 & $<0.01$ & $<0.01$ & 0.43 \\
\hline \multicolumn{9}{|c|}{ Cumulative $\%$ of daily intake } \\
\hline $8 \mathrm{~h}$ & $63.6^{\mathrm{a}}$ & $61.4^{\mathrm{a}}$ & $54.0^{\mathrm{b}}$ & $55.1^{\mathrm{b}}$ & 2.14 & $<0.01$ & 0.71 & 0.32 \\
\hline $16 \mathrm{~h}$ & $92.9^{\mathrm{a}}$ & $91.2^{\mathrm{a}}$ & $86.8^{\mathrm{b}}$ & $86.3^{\mathrm{b}}$ & 1.33 & $<0.01$ & 0.31 & 0.57 \\
\hline Refusal, \% & 9.9 & 9.8 & 10.6 & 9.9 & 0.39 & 0.21 & 0.23 & 0.39 \\
\hline
\end{tabular}

${ }^{\mathrm{a}-\mathrm{d}}$ Means within a row with different superscripts differ $(P \leq 0.05)$.

${ }^{1} \mathrm{LC}=$ long corn silage and dry cracked corn; $\mathrm{LF}=$ long corn silage and dry fine ground corn; SC = short corn silage and dry cracked corn; SF $=$ short corn silage and dry fine ground corn.

${ }^{2}$ Approximate equivalency to Penn State Particle Separator (The Pennsylvania State University, University Park): top sieve (26.9 + 18.0 mm), middle sieve $(8.98 \mathrm{~mm})$, lower sieve $(5.61+1.65 \mathrm{~mm})$, and pan (pan). 
Table 9. Effect of feeding TMR varying in forage particle size (FPS) and ruminally fermentable carbohydrates (RFC) on milk yield and components

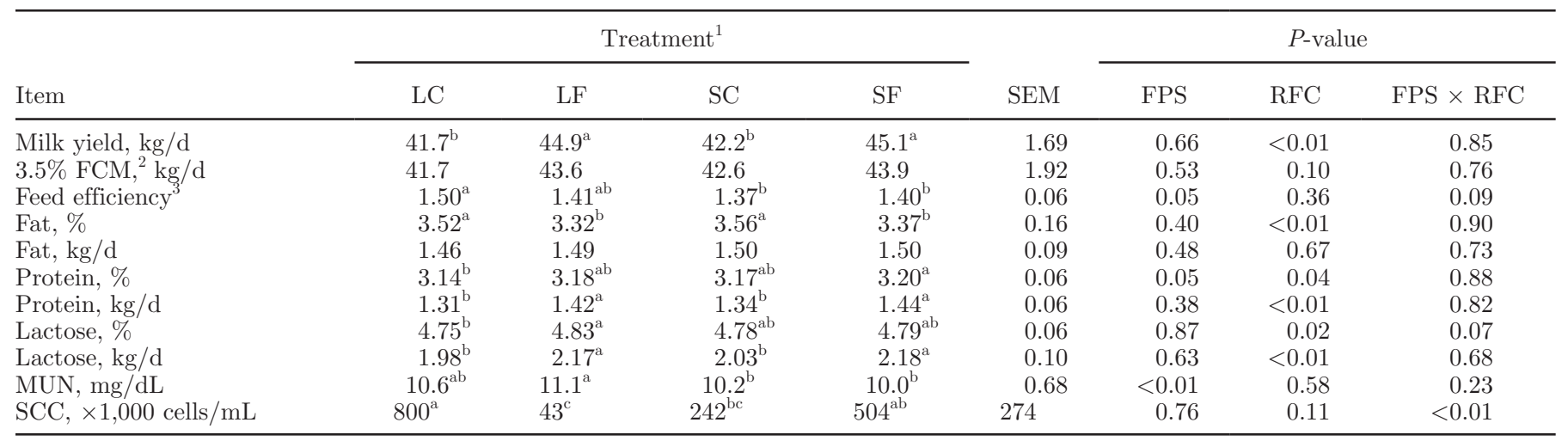

${ }^{a-c}$ Means within a row with different superscripts differ $(P \leq 0.05)$.

${ }^{1} \mathrm{LC}=$ long corn silage and dry cracked corn; $\mathrm{LF}=$ long corn silage and dry fine ground corn; $\mathrm{SC}=$ short corn silage and dry cracked corn; SF $=$ short corn silage and dry fine ground corn.

${ }^{2} 3.5 \% \mathrm{FCM}=0.432(\mathrm{~kg}$ of milk) +16.23 ( $\mathrm{kg}$ of fat) (Gaines, 1928).

${ }^{3}$ Feed efficiency $=3.5 \%$ FCM $/$ DMI.

yield, it also decreased milk fat content (from 3.54 to $3.35 \%$, on average) and, therefore, 3.5\% FCM only tended to be higher with higher RFC levels. Increasing RFC also increased milk protein concentration and yield and lactose concentration and yield. This is likely an effect of increasing available energy in the rumen, which can increase microbial protein synthesis and propionate production. These changes in milk yield and composition were not preceded by changes in ruminal fermentation as measured in this study. A possible explanation for this discrepancy is that only the concentrations of ruminal compounds were measured, and actual production and absorption of VFA and $\mathrm{NH}_{3}$ are not known. Increasing FPS decreased milk protein concentration and increased MUN levels; this could be due to insufficient available energy for ruminal microorganisms to allow then to effectively utilize available $\mathrm{NH}_{3}$. Feed efficiency increased with increasing FPS as a result of longer FPS decreasing DMI while maintaining $3.5 \%$ FCM.

\section{CONCLUSIONS}

It was determined that increasing RFC increased ruminating time and increasing FPS increased eating time. Ruminal fermentation was not affected by either FPS or RFC, although increasing FPS tended to increase mean and maximum ruminal $\mathrm{pH}$ and increasing $\mathrm{RFC}$ tended to decrease minimum ruminal $\mathrm{pH}$. Refusal particle size distribution and NDF and starch content were observed to change over the course of the day and indicated that cows were sorting against peNDF and for RFC. Analysis of selection indices revealed that virtually no interaction between FPS and RFC occurred and despite significant sorting throughout the day, by $24 \mathrm{~h}$ after feeding cows had consumed a ration very similar to what was offered. This view of sorting was reinforced by particle fraction intakes that very closely resembled the proportions of particle fractions in the offered TMR. An interaction between FPS and RFC was observed for DMI, as DMI decreased with increasing FPS when the diet included low RFC and did change when the diet included high RFC, and DMI increased with RFC for the long diets and did not change with RFC on the short diets. Increasing RFC was found to increase milk yield, milk protein content and yield, and lactose content and yield but to decrease milk fat content. Increasing FPS did not have as great an effect on milk production as RFC. The authors, therefore, concludes that there was not significant interaction between FPS and RFC for ration sorting, although both affected it separately; RFC had greater influence on milk yield and components than FPS; neither FPS nor $\mathrm{RFC}$ affected ruminal fermentation; and there was an interaction between FPS and RFC for DMI. This study revealed that forage length and starch availability had no significant effects on rumen $\mathrm{pH}$ and fermentation. Intake of TMR decreased with increased forage particle size, whereas diet fermentable carbohydrate level increased milk yields and components except for fat level, which decreased. Diet particle size significantly affected the cows' eating patterns and their ability to sort rations. The combination of forage particle length and starch availability can, however, have large effects on intake and production and both are important in ration balancing. 


\section{ACKNOWLEDGMENTS}

Sincere appreciation is extended to Growmark FS LLC (Sangerfield, NY) for generously allowing the use of their modified forage harvester for the duration of this trial. This research was supported in part by agricultural research funds administered by The Pennsylvania Department of Agriculture.

\section{REFERENCES}

ASABE (American Society of Agricultural and Biological Engineers). 2007. Method of determining and expressing particle size of chopped forage materials by screening. ANSI/ASAE S424.1:663665. ASABE, St. Joseph, MI.

AOAC International. 2000. Official Methods of Analysis. 17th ed. AOAC International, Arlington, VA.

Bailey, C. B. 1961. Saliva secretion and its relation to feeding in cattle. Br. J. Nutr. 15:443-451.

Beauchemin, K. A., L. Eriksen, P. Nørgaard, and L. M. Rode. 2008. Short communication: Salivary secretion during meals in lactating dairy cattle. J. Dairy Sci. 91:2077-2081.

Broderick, G. A., and J. H. Kang. 1980. Automated simultaneous determination of ammonia and total amino acids in ruminal fluid and in vitro media. J. Dairy Sci. 63:64-75.

Gaines, W. L. 1928. The energy basis of measuring milk yield in dairy cows. Illinois Agricultural Experiment Station Bulletin 308. University of Illinois Agricultural Experiment Station, Urbana.

Kenward, M. G., and J. H. Roger. 1997. Small sample inference for fixed effects from restricted maximum likelihood. Biometrics 53:983-997.

Kononoff, P. J., and A. J. Heinrichs. 2003. The effect of corn silage particle size and cottonseed hulls on cows in early lactation. J. Dairy Sci. 86:2438-2451.

Kononoff, P. J., A. J. Heinrichs, and D. R. Buckmaster. 2003a. Modification of the Penn State forage and total mixed ration particle separator and the effects of moisture content on its measurements. J. Dairy Sci. 86:1858-1863.

Kononoff, P. J., A. J. Heinrichs, and H. A. Lehman. 2003b. The effect of corn silage particle size on eating behavior, chewing activities, and rumen fermentation in lactating dairy cows. J. Dairy Sci. $86: 3343-3353$.

Kononoff, P. J., H. A. Lehman, and A. J. Heinrichs. 2002. Technical note - A comparison of methods used to measure eating and ruminating activity in confined dairy cattle. J. Dairy Sci. 85:18011803.

Krause, K. M., and D. K. Combs. 2003. Effects of forage particle size, forage source, and grain fermentability on performance and ruminal $\mathrm{pH}$ in midlactation cows. J. Dairy Sci. 86:1382-1397.
Krause, K. M., D. K. Combs, and K. A. Beauchemin. 2002a. Effects of forage particle size and grain fermentability in midlactation cows. I. Milk production and diet digestibility. J. Dairy Sci. 85:19361946.

Krause, K. M., D. K. Combs, and K. A. Beauchemin. 2002b. Effects of forage particle size and grain fermentability in midlactation cows. II. Ruminal pH and chewing activity. J. Dairy Sci. 85:1947-1957.

Leonardi, C., and L. E. Armentano. 2003. Effect of quantity, quality, and length of alfalfa hay on selective consumption by dairy cows. J. Dairy Sci. 86:557-564.

Leonardi, C., F. Giannico, and L. E. Armentano. 2005. Effect of water addition on selective consumption (sorting) of dry diets by dairy cattle. J. Dairy Sci. 88:1043-1049.

Littell, R. C., P. R. Henry, and C. B. Ammerman. 1998. Statistical analysis of repeated measures data using SAS procedures. J. Anim. Sci. 76:1216-1231.

Maulfair, D. D., M. Fustini, and A. J. Heinrichs. 2011. Effect of varying total mixed ration particle size on rumen digesta and fecal particle size and digestibility in lactating dairy cows. J. Dairy Sci. 94:3527-3536.

Maulfair, D. D., G. I. Zanton, M. Fustini, and A. J. Heinrichs. 2010. Effect of feed sorting on chewing behavior, production, and rumen fermentation in lactating dairy cows. J. Dairy Sci. 93:4791-4803.

NRC. 2001. Nutrient Requirements of Dairy Cattle. 7th rev. ed. Natl. Acad. Sci., Washington, DC.

Rutter, S. M. 2000. Graze: A program to analyze recordings of the jaw movements of ruminants. Behav. Res. Methods Instrum. Comput. 32:86-92

Rutter, S. M., R. A. Champion, and P. D. Penning. 1997. An automatic system to record foraging behaviour in free-ranging ruminants. Appl. Anim. Behav. Sci. 54:185-195.

Schwab, C. G., T. P. Tylutki, R. S. Ordway, C. Sheaffer, and M. D. Stern. 2003. Characterization of proteins in feeds. J. Dairy Sci. 86(E. Suppl.):E88-E103.

Shipley, R. A., and R. E. Clark. 1972. Tracer Methods for In Vivo Kinetics. Academic Press, New York, NY.

Van Soest, P. J., J. B. Robertson, and B. A. Lewis. 1991. Methods for dietary fiber, neutral detergent fiber, and nonstarch polysaccharides in relation to animal nutrition. J. Dairy Sci. 74:3583-3597.

Yang, C.-M. J., and G. A. Varga. 1989. Effect of three concentrate feeding frequencies on rumen protozoa, rumen digesta kinetics, and milk yield in dairy cows. J. Dairy Sci. 72:950-957.

Yang, W. Z., K. A. Beauchemin, and L. M. Rode. 2001. Effects of grain processing, forage to concentrate ratio, and forage particle size on rumen $\mathrm{pH}$ and digestion by dairy cows. J. Dairy Sci. 84:2203-2216.

Zanton, G. I., and A. J. Heinrichs. 2009. Digestion and nitrogen utilization in dairy heifers limit-fed a low or high forage ration at four levels of nitrogen intake. J. Dairy Sci. 92:2078-2094. 